\title{
고려〈청산별곡〉과 조선〈강보〉의 관계 \\ The Relationship of Cheongsanbyeolgok in \\ Goryeo Dynasty and Gangbo in Joseon Dysnaty
}

\author{
정경란 \\ 한국학중앙연구원 \\ Kyung Rhan Chung(chung311@aks.ac.kr)
}

\section{요약}

<청산별곡(靑山別曲)>은 고려시대에 지어진 작자 미상의 가요이며, <강보(降寶)>는 조선 세종이 종묘, 조회, 공연에 사용하기위해 새로 창제한 <발상(發祥)> 11 곡 중의 한 곡이다. 『세종실록(世宗實錄)』에 의하 면 <발상>은 고취악과 향악에 의하여 창제되었다고 하였으므로 이 기록에 근거하여 이 논문은 <발상> 중 <강보>가 고려 향악인 <청산별곡>에 근거하여 창제되었음을 밝힌 논문이다.

<강보>와<청산별곡>의 선율을 비교 분석한 결과 48 행의 <강보>는 10 행의 <청산별곡>을 세 번 반복 하였는데, 즉 <강보>의 1-16행, 17-32행, 33-48행에서<청산별곡>이 세 번 반복하여 발췌되었고, <청산 별곡>과 <강보>의 선율은 거의 같거나 유사함을 알 수 있었다.

세종 때<발상> 중의 <강보>가 고려 향악인 <청산별곡>을 발췌하여 신악(新樂)으로 창제되었음을 이 연구에서 밝혀냈다.

- 중심어 : | 발상 | 강보 | 청산별곡 | 세종실록악보 | 시용향악보 |

\section{Abstract}

Chongsanbyeolgok is one of Goryeo songs which might be composed in Goryeo dynasty, the composer of which is not known as well as other Goryeo songs. Balsang songs is structured with eleven songs that has been composed newly by King Sejong in Joseon Dynasty for using at Jongmyo (royal ancestral shrine), Johoe (royal audiences), performance, Gangbo is one of 11 songs in Balsang. In Sejongsillok, it is written that Balsang was composed by taking the melody and rhythm of gochwiak (processional music) or hyangak. Thus, it is interesting to know how gochwiak and hyangak, especially Chongsanbyeolgok affected structure and rhythm of Gangbo.

As an analytical result of Gangbo and Chongsanbyeolgok, Gangbo consisted of 48 Haeng(line) repeated Chongsanbyeolgok's melody (10 Haeng) by three times. That is, 1-16, 17-32, and 33-48 Haeng of Gangbo excerpted from Cheongsanbyeolgok's melody, and those melodies of Gangbo are same or similar to Chongsanbyeolgok. In this report, Gangbo, one of Balsang's musics in Jos 대n Dynasty is proven to be excerpted from the melody of Chongsanbyeolgok in Goryeo Dynasty and repeated.

- keyword : | Balsang | Gangbo | Cheongsanbyeolgok | Sejongsillok-akbo | Siyonghyang-akbo |

* 본 논문은 한국콘텐츠학회 2013 춘계 종합학술대회 우수논문입니다. 


\section{I. 서 론}

<청산별곡(靑山別曲)>은 고려시대에 지어진 작자 미상의 가요로『악장가사(樂章歌詞)』[1]와『악학편고 (樂學便考)』[2]에 악보 없이 8연의 가사가 전하고, 『시 용향악보(時用鄉樂譜)』[3]에 악보와 함께 가사 제 1 연이 전한다.

<청산별곡>은 고려 때의 무가인 <대국(大國)>과 동 일한 곡으로 언급하기도 하였고, 1393년(태조 2년)에는 정도전(鄭道傳)이<청산별곡>을 발췌하여 <납씨가(納 氏歌 $>$ 를 만들었다고 하였다[4]. 조선 세종 때에는 평 조의 <청산별곡>을 계면조로 고쳐서 <정대업(定大 業)> 중의 <휴명(休命)>이 만들어지고, <휴명>은 다 시 세조 때 남려궁에서 청황종궁으로 바뀌어<총유(寵 緌)>로 전승된다[5]. 세조 때에는 10행의 <청산별곡> 에 2행을 첨가하여 12 행의 <경근지곡(敬勤之曲)>이 만 들어지기도 하였다[6].

이처럼 고려의 <청산별곡>은 고려의 <대국>, 조선 의 <납씨가 $>\cdot\langle$ 휴명 $>\cdot\langle$ 총유 $>\cdot<$ 경근지곡 $>$ 등에서 선율이 발췌되거나, 조(調)가 바뀌고, 악곡의 길이가 증 가되는 등 다양하게 변모되어 전승되었다.

또한 조선 세종 때의 <발상(發祥)>은 조상(祖上)이 하늘에서 내린 상서(祥瑞)를 받았다는 것을 노래와 춤 으로 나타낸 무곡(舞曲)으로 모두 11 곡으로 이루어졌 고, 남려(南呂)를 중심음으로 하는 평조이다[7]. <발 상 $>$ 의 11 곡은 <희광(熙光) $>\cdot<$ 순우(純佑) $>\cdot<$ 창부(昌 符 $)>\cdot\langle$ 영경(靈慶) $\rangle \cdot\langle$ 신계(神啓 $)\rangle \cdot\langle$ 현휴(顯休) $\rangle \cdot\langle$ 정 희 (禎禧 $)>\cdot<$ 강보 (降寶) $>\cdot<$ 응명 (凝命) $>\cdot<$ 가서 $($ 嘉 瑞) $>\cdot<$ 화성(和成) $>$ 이며, <강보>는 여덟 번째 곡이다. 세종은 고취악과 향악에 인하여 신악(新樂)인 <정대 업 $>\cdot<$ 보태평 $($ 保太平) $>\cdot<$ 발상 $>\cdot<$ 봉래의(鳳來儀) $>$ 를 창제하였고1[8], 실제 <정대업> 과 <보태평>의 악곡들 중 <순응(順應) >은 <만전춘(滿殿春) >에서, <화태(和 泰) $>$ 는 <서경별곡(西京別曲) $>$ 에서, <형광(亨光) >은 $<$ 귀호곡(歸乎曲) >에서, <보예(保义) >는 <야심사(夜深 詞)>에서, <융화(隆化) >는 <풍입송(風入松) >에서 발

1『世宗實錄』138권. 1a2-4："國朝鼓吹樂曰 愛寶籙 夢金尺 唓天庭 受 明命 皆各主一事未足以形容 租宗功德之盛大 締造之熯難 世宗因鼓 吹樂 及鄉樂創爲新樂曰 定大業 保太平 發祥 鳳來儀 今謹錄云”
췌하여 세종의 신악으로 창제되었음이 연구된 바 있다 [5]. 그러나 <발상>과 고려 향악과의 관계에 대하여는 아직 연구된 바가 없으므로[9][10], 이 연구에서는 <발 상> 중 <강보>가 고려 향악인 <청산별곡>에서 어떻 게 영향을 받아 창제되었는지를 살펴보았다.

연구방법으로는 『시용향악보』에 수록된 <청산별 곡>과『세종실록악보』에 수록된 <강보>의 선율 비교 분석을 통하여 <청산별곡>과 <강보>의 관련성을 살 펴보았다.

\section{II. 청산별곡, 발상, 강보의 개요}

\section{1 청산별곡의 개요}

<청산별곡>의 제작 시기는 분명하지 않으나 대체로 고려후기로 알려져 있으며, 작자에 대해서도 귀족계급, 농민, 유민, 농민반란군, 관기나 관노, 평민 등 다양한 계층으로 추정되었다[표 1].

\section{표 1.〈청산별곡〉의 창작연대 및 유행시기와 그 추정근거} [11]

\begin{tabular}{|c|c|c|}
\hline 연구자 & 창작연대 및 유행시기 & 근거 \\
\hline 장지영 & 고려시대 중기 이후 말기 사이 & 情調의 순진함과 詞格의 古朴함으로 보아 \\
\hline 김택규 & 12세기 초 이후 & $\begin{array}{c}\text { 새로 들어온 가락에 맞추어 새 가락과 새 } \\
\text { 사설을 변용시킨 것 }\end{array}$ \\
\hline 이동근 & 인종 대 & $\begin{array}{c}\text { 이자겸의 반란(1126), 묘청의 난(1135) 때 } \\
\text { 은둔을 경험한 자의 창작 }\end{array}$ \\
\hline 김언종 & 의종 연간 & 의종세가와 열전의 宦者傅 嬖幸傳 \\
\hline 서수생 & $\begin{array}{c}\text { 고종(1216 1259)조 전후 } \\
\text { 늦어도 이제현의 소악부 성립 } \\
\text { 시기(1342) 이전 }\end{array}$ & 내용 - 형식 · 사회적 배경으로 유추 \\
\hline 박노준 & $\begin{array}{c}\text { 몽고족의 2차 내침이 있던 고종 } \\
19 \text { 년(1232) 이후 고종 } 44 \text { 년(1257) } \\
\text { 사이 }\end{array}$ & $\begin{array}{c}\text { 몽고족의 침입으로 徙民山城海島의 명을 } \\
\text { 내려 항몽전이 시작되었기에 }\end{array}$ \\
\hline 최기호 & $\begin{array}{l}\text { 몽골의 제1차 일본정벌(1274)보다 } \\
3 \text { 년 전인 1271 1281년 전후 }\end{array}$ & $\begin{array}{l}\text { 몽골이 일본정벌을 위하여 전함을 만들 때 } \\
\text { 주민들이 극심한 피해를 입었기 때문 }\end{array}$ \\
\hline 임주탁 & 강화도 천도 시기 & $\begin{array}{c}\text { ‘노마자기란 말이 강화를 포함한 황해도 } \\
\text { 평안도 지역에 쓰임으로 보아 }\end{array}$ \\
\hline 김형기 & $\begin{array}{c}1280 \sim 1282 \text { 년. } \\
\text { 충렬왕 } 7 \text { 년(1281) 전후 }\end{array}$ & $\begin{array}{c}\text { 노래 속에 그려진 풍경이 } 1274 \text { 년 및 } \\
1279 \sim 1280 \text { 년의 일이니까 }\end{array}$ \\
\hline
\end{tabular}

『악장가사』에는 악보 없이 <청산별곡>의 가사만 모 두 8연이 수록되어 있으며, 그 가사와 원문은 [표 2], [표 3]과 같다. 


\section{표 2.『악장가사』의〈청산별곡〉가사}

\begin{tabular}{|c|c|}
\hline 구성 & 가사 \\
\hline 1연 & 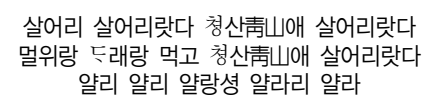 \\
\hline 2연 & $\begin{array}{c}\text { 우러라 우러라 새여 자고 니러 우러라 새여 } \\
\text { 널라와 시름 한 나도 자고 니러 우리노라 } \\
\text { 얄리 얄리 얄랑셩 얄라리 얄라 }\end{array}$ \\
\hline 3연 & $\begin{array}{c}\text { 가던 새 가던 새 본다 믈아래 가던 새 본다 } \\
\text { 잉무든 장글란 가지고 들아래 가던 새 본다 } \\
\text { 얄리 얄리 얄랑셩 얄라리 얄라 }\end{array}$ \\
\hline 4연 & $\begin{array}{c}\text { 이랑공 뎌링공 흐야 나즈란 디내와손뎌 } \\
\text { 오리도 가리도 업슨 바므란 쏘 엇디 호리라 } \\
\text { 얄리 얄리 얄랑셩 얄라리 얄라 }\end{array}$ \\
\hline 5연 & $\begin{array}{c}\text { 어드라 더디던 돌코 누리라 마치던 돌코 } \\
\text { 미리도 괴리도 업시 마자셔 우니노라 } \\
\text { 얄리 얄리 얄랑셩 얄라리 얄라 }\end{array}$ \\
\hline 6연 & $\begin{array}{c}\text { 살어리 살어리랏다 바래 살어리랏다 } \\
\text { 노마지기 구조개랑 먹고 바르래 살어리랏다 } \\
\text { 얄리 얄리 얄랑셩 얄라리 얄라 }\end{array}$ \\
\hline 7연 & $\begin{array}{c}\text { 가다가 가다가 드로라 에졍지 가다가 드로라 } \\
\text { 사스미 짔대에 올아셔 히금을 혀거를 드로라 } \\
\text { 얄리 얄리 얄랑셩 얄라리 얄라 }\end{array}$ \\
\hline 8연 & $\begin{array}{c}\text { 가다니 비브론 도긔 설진 강수를 비조라 } \\
\text { 조롱곳 누로기 미와 잡와니 내 엇디 흐ㄹㅣㅣㅣㅅㄱㅗ } \\
\text { 얄리 얄리 얄랑셩 얄라리 얄라 }\end{array}$ \\
\hline
\end{tabular}

\section{표 3.『악장가사』의〈청산별곡〉 원문}

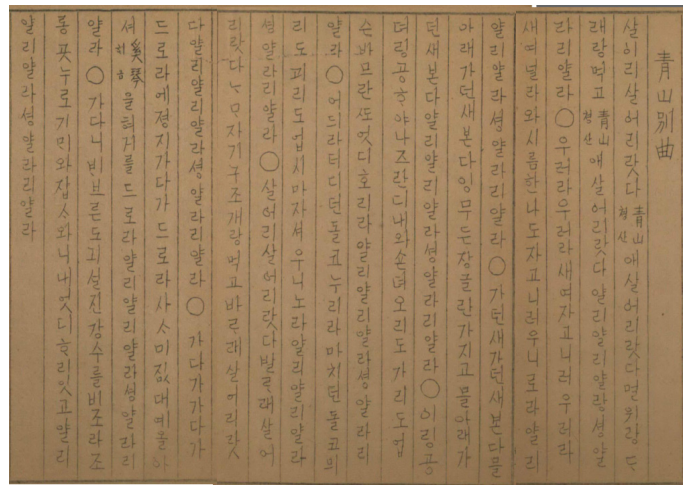

『악학편고』에도『악장가사』와 마찬가지로 <청산별 곡>의 8 연의 가사가 수록되어 있으며, 그 가사와 원문 은 [표 4], [표 5]와 같다.

\section{표 4. 『악학편고』 의〈청산별곡〉가사}

\begin{tabular}{|c|c|}
\hline 구성 & 가사 \\
\hline 1연 & 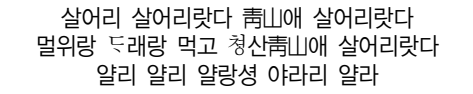 \\
\hline 2연 & $\begin{array}{c}\text { 우러라 우러라 새여 사고 니러 우러라 새여 } \\
\text { 널라와 시름 한 나도 자고 니러 우니노라 } \\
\text { 얄리 얄리 얄랑셩 얄라리 얄라 }\end{array}$ \\
\hline 3연 & $\begin{array}{c}\text { 가던 새 가던 새 본다 믈아래 가던 새 본다 } \\
\text { 잉무든 장글란 가지고 믈아래 가던 새 본다 } \\
\text { 얄리 얄리 얄랑셩 얄라리 얄라 }\end{array}$ \\
\hline 4연 & $\begin{array}{c}\text { 이랑공 뎌링공 햐야 이즈란 지내와손뎌 } \\
\text { 오리도 가리도 업슨 바므란 쏘 엇지 호리라 } \\
\text { 얄리 얄리 얄라셩 얄라리 얄라 }\end{array}$ \\
\hline 5연 & $\begin{array}{l}\text { 어듸라 더디던 돌코 누리라 마치던 돌코 } \\
\text { 미리도 괴리도 업시 마자셔 우니노라 } \\
\text { 얄리 얄리 얄랑셩 얄라리 얄라 }\end{array}$ \\
\hline 6연 & $\begin{array}{c}\text { 살어리 살어리랏다 바르래 살러리랏다 } \\
\text { 느마기 구조개랑 먹고 바르래 살러리랏다 } \\
\text { 얄리 얄리 얄랑셩 얄라리 얄라 }\end{array}$ \\
\hline 7연 & $\begin{array}{c}\text { 가다가 가다가 도로라 에졍지 가다가 도로라 } \\
\text { 사소미 지대예 올아셔 奚琴히금을 혜거를 드로라 } \\
\text { 얄리 얄리 얄랑셩 얄라리 얄라 }\end{array}$ \\
\hline 8연 & $\begin{array}{c}\text { 가다니 비브ㄹㅡㅡ 도긔 설진 강수를 비조라 } \\
\text { 조롱곳 누로기 믜와 잡ㅅㅅ와니 내 엇지 흐리잇고 } \\
\text { 얄리 얄리 얄랑셩 얄라리 얄라 }\end{array}$ \\
\hline
\end{tabular}

\section{표 5. 『악학편고 의〈청산별곡〉원문}

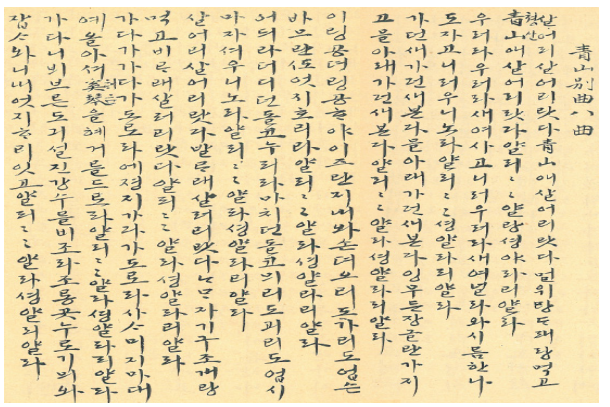

또한 『시용향악보』에는 악보와 함께 <청산별곡>의 가사 제 1 연만 실려 있다. 『시용향악보』의 <청산별곡> 은 평조이고, 16 정간 1 행의 10 행으로 이루어져 있으며, 가사와 악보는 [표 6], [악보 1]과 같다.

\section{표 6.『시용향악보』의〈청산별곡〉가사}

\begin{tabular}{|c|c|}
\hline 구성 & 가사 \\
\hline 1연 & $\begin{array}{c}\text { 살어리 살어리라따 컬의 살어리랏다 } \\
\text { 앙 대랑 바먹고 靑山의 살어리랏다 } \\
\text { 얄리 얄리 얄라 얄라셩 얄라 }\end{array}$ \\
\hline
\end{tabular}


악보 1. 『시용향악보 의〈청산별곡〉악보

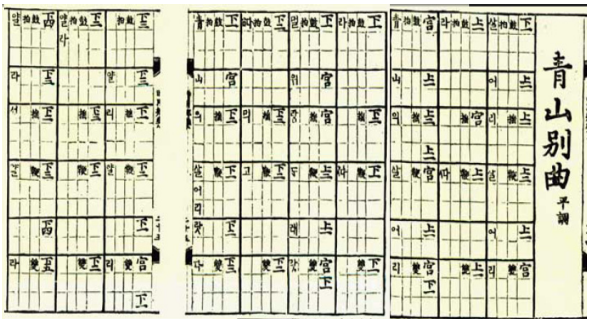

<청산별곡>에 대해서는 고려의 <대국>, 조선의 <납씨가>, 세종 때 정대업 중의 <휴명>, 세조 때<총 유>, <경근지곡>과 선율 상 관련이 있음이 밝혀진 바 있다.

\section{2 발상의 개요}

<발상>에 대한 기록은 『세종실록』에 처음 나온다. 세종 29년(1447년) 6월 4일 기록에는 “상서(祥瑞)의 감 응된 바를 취재(取才)하여 따로 한 가지 곡조를 지었는 데, 이름을 “발상(發祥)' 이라 하여, 악보 1권이 있었다”2 고 하였다.

또한 세종 31년(1449년) 10월 3일 기록에는 “종묘(宗 廟)·조회(朝會)·공연(公宴)의 음악에 전조(前朝)의 잡성 (雜聲)을 엮어 넣음은 심히 타당하지 못하오니, 지금 새 로 정한 제악(諎樂)과 구악(舊樂) 안에서 쓸 만한 여러 소리[諸聲]를 다시 더 산정(刪定)하게 하시되, 발상 정 재(發祥呈才) 11 성(聲), 정대업 정재(定大業呈才) 15성, 보태평 정재(保太平呈才) 11 성, 봉래의 정재(鳳來儀呈 才) 5성, 외양선 정재(外羊仙呈才) 6성, 포구락 정재(抛 毬樂呈才) 4 성, 연화대 정재(蓮花臺呈才) 4성, 처용 정 재(處容呈才) 3 성, 동동 정재(動動呈才) 1 성, 무애 정재 (無昌呈才) 1 성, 무고 정재(舞鼓呈才) 3 성, 향발 정재(響 鈸呈才) 1 성과 제악(祭樂)으로 초헌(初獻) 1성, 아헌(亞 獻) 1 성, 종헌(終獻) 1 성과 여민락만(與民樂慢) 1 성, 치 화평중(致和平中) 2 성, 진작 사체(眞勺四體) 4성 등 합 계 75성(聲)으로써 항상 예습(隷習)하게 하옵소서”3 라

2『世宗實錄』116권 22a："又取瑞應 別作一舞 號發祥 有譜一卷" 3『世宗實錄』126권 2a："庚戊議政府據䣓曹啓申 宗廟、朝會、公宴之 樂, 掇拾前朝雜聲, 深爲未便。今新定諸樂及舊樂之內, 可用諸聲, 更 加刪定。《發祥》呈才十一馨, 《定大業》呈才十五聲, 《保太平》呈 才十一聲, 《鳳來儀》呈才五聲, 《外羊仙》呈才六聲, 《扰捄樂》呈
고 하여 <발상>을 종묘, 조회, 공연의 음악에 사용하였 던 것을 볼 수 있다.

세조 6년(1460년) 4월 22일 기록에는 "지금부터 정대 업(定大業)·보태평(保太平)·발상(發祥)·봉래의(鳳來儀) 의 신악(新樂)을 익히고 구악(舊樂)을 다 폐지하라"4하 여 세조 때에는 <발상>과 같은 신악을 익히게 하였음 을 알 수 있다.

송방송은 <발상> 정재가 전승되지 않은 이유로 <발 상> 11 곡의 내용이 <보태평> 11 곡이나 <정대업> 15 곡과 비슷하므로, <보태평>·<정대업>의 정재공연으 로 충분했기 때문이 아닐까 추정하였다[9].

<발상>은 세종 29년(1447년)부터 세조 6년(1460년) 까지의 기록에만 나오고 음악도 전승되고 있지 않기 때 문에 세종 때 창제되어 세조이후 언제까지 전승되었는 지는 알 수 없다. 또한『대악후보』나『악학궤범』등에 도 모습이 보이지 않고 오직『세종실록악보』에서만 악 곡을 찾아볼 수 있다.

\section{3 강보의 개요}

$<$ 강보(降寶) >는 <발상>의 11곡 중 여덟 번째 곡이 다. <강보>는 태조(太祖)의 잠저(潛邸) 때에, 어떤 중이 이상한 글을 바치면서, 지리산 바위 속에서 얻었다고 하는데, 그 글에 "목자(木子)가 돼지를 타고 내려와서, 다시 삼한(三韓)의 땅을 바로잡으리라”고 하는 귀절이 있었다는 것을 노래한 것으로, 이런 이야기는 용비어천 가 제 86 <여섯노루> 장에도 나오고, 또 태조(太租) 5 년 에 정도전(鄭道傳)이 바친 수보록(受寶籙)에도 보인다 [7].

『세종실록악보』에 수록된 이 곡의 음계는 남려(南 呂)·응종(應鐘)· 태주(太簇)·고선(姑洗)·유빈(蓕賓)의 5 음 음계이며, 선법은 남려궁 평조이다. 4 언절구의 한문 가사에서 박(拍)이 4 언 1 구마다 한 번씩 규칙적으로 사 용된다. 32 정간의 1 행의 총 24 행으로 이루어졌고, 16 정

才四聲, 《蓮花臺》呈才四聲, 《處容》呈才三聲, 《動動》呈才一聲, 《無导》呈才一聲, 《舞鼓》呈才三聲, 《響鈜》呈才一聲, 《祭樂》 初獻一聲、亞獻一聲、終獻一聲, 《與民樂》漫一聲、《致和平》中 二聲、《黄匀》四體四聲, 凡七十五聲, 常令知習"

4 『世租實錄』20권 $14 \mathrm{~b}$ ：" 自今肄《定大業》、《保太平》、《發 祥》、《鳳來儀》新樂而盡廢舊樂” 
간 1행으로 본다면 총 48행으로 이루어졌다고 할 수 있 다.

『세종실록악보』에 수록된 <강보>는 [악보 2]와 같다.

악보 2.『세종실록악보』 의〈강보〉악보[12]

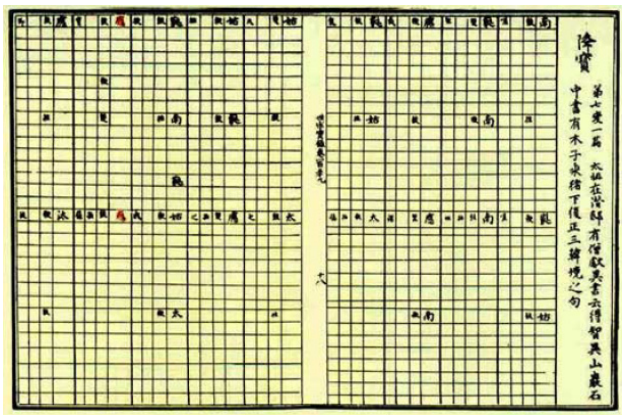

<발상>에 대한 음악적 연구, 특히 <발상> 음악이 창 작된 근원인 고취악, 향악과 <발상>과의 관계에 대한 연구는 아직 찾아볼 수 없으며, 또한 <강보>에 대한 연 구도 찾아볼 수 없다. 이 연구에서는 <발상> 중 <강 보>와 고려향악인 <청산별곡>의 관계를 살펴볼 것이 다.

\section{III. 청산별곡과 강보의 악곡 비교}

『세종실록악보』의 <강보>는 율자보(律字譜)로 기보 되어있고, <청산별곡>이 수록된 『시용향악보』는 오음 약보로 되어 있다. <발상>은 남려궁평조(南呂宮本調) 이므로 <강보> 역시 남려궁평조로 남려가 궁이 된다.

『세종실록악보』의 <강보>는 32정간 1 행으로 되어 있으나, 『시용향악보』의 <청산별곡>은 16 정간 1 행으 로 되어 있으므로『시용향악보』<청산별곡>과의 비교 를 위하여『세종실록악보』의 <강보>도 16 정간을 1 행, 32 정간을 2 행으로 간주하여 비교한다. 또한 오음약보의 <청산별곡>과의 비교를 위하여 율자보로만 기보된 <강보>를 오음약보로도 병기하여 비교 분석한다. 남려 궁평조의 율자보와 오음약보의 비교는 [표 7]과 같다.

\section{표 7. 남려궁평조의 율자보와 오음약보 비교}

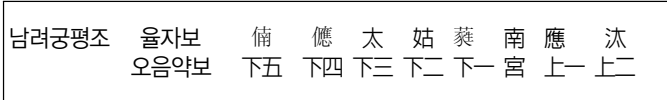

『시용향악보』의 <청산별곡>과 『세종실록악보』의 <강보> 악곡을 비교해 보겠다.

<강보> 1-2행의 ‘南豚姑(오음약보로는 宮下一下二 임)'의 선율과 거의 동일한 <청산별곡>의 선율은 3 행 제 14 정간부터 4 행 제 8 정간의 “宮下一下-下二’이다[악 보 3][악보 4].

악보 3. 〈강보〉1-2행과〈청산별곡〉 3 행 제 14 정간-4행 제8정간의 악보 비교

\begin{tabular}{|c|c|c|c|c|}
\hline \begin{tabular}{|l|} 
강보 1-2행 \\
(세종실록악보)
\end{tabular} & 南 & 䕰 & & 姑 \\
\hline $\begin{array}{l}\text { 청산별곡 3행 제14 } \\
\text { 정간-4행 제8정간 } \\
\text { (시용햐안갑) }\end{array}$ & 谷 & F & F & $\begin{array}{l}\text { F } \\
=\end{array}$ \\
\hline
\end{tabular}

악보 4. 〈강보〉1-2행과〈청산별곡〉 3행 제14정간-4행 제8정간의 선율비교

\begin{tabular}{|c|c|}
\hline $\begin{array}{l}\text { 강보 1-2행 } \\
\text { - 세종실록악보 } \\
\text { - 오음약보 바꾼 악보 }\end{array}$ & $\begin{array}{c}\text { 南莛 } \\
\text { 宮下 } \quad \text { 下二 }\end{array}$ \\
\hline $\begin{array}{c}\text { 청산별곡 3핵 제14정간-4행 } \\
\text { 제8정간 } \\
\text { (시용향박보) }\end{array}$ & 宮下-下-下二 \\
\hline
\end{tabular}

<강보> 3-6행의 “蓕南南應應南(오음약보로는 下一 宮宮上一上一宮임)'과 동일한 <청산별곡>의 선율은 “下一宮宮上二上一宮”으로 5 행 제 1 정간부터 제 14 정간까 지에 해당한다. <강보>에서는 5 행 제 1 정간의 '應(오음 약보로는 上-임)'이 6행에 이어 한 번 더 나오고 있지 만, <청산별곡> 5행 12정간에 '上-'이 나오고 있어, 13 정간에는 그 '上-'을 계속 끌어주는 것으로 볼 수 있다. <청산별곡>의 5행 제9정간에 나오는 '上二'를 <강보> 3-6행에서는 볼 수 없다[악보 5][악보 6].

악보 5. 〈강보〉 3-6행과 〈청산별곡〉 5행 제 1 정간-제 14 정 간의 악보 비교

\begin{tabular}{|c|c|c|c|c|c|c|}
\hline 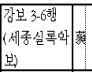 & 南 & $\mid \frac{1}{P}$ & & 嵟 & 布 & 南 \\
\hline 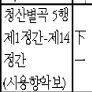 & 宮 & 宮 & $\begin{array}{l}\text { 上 } \\
\text { 二 }\end{array}$ & 上- & & 言 \\
\hline
\end{tabular}


악보 6. 〈강보〉 $3-6$ 행과 〈청산별곡〉 5 행 제 1 정간-제 14 정 간의 선율비교

\begin{tabular}{|c|c|}
\hline $\begin{array}{l}\text { 강보 3-6행 } \\
\text { - 세종실록악보 } \\
\text { - 오음약보로 바꾼 악보 }\end{array}$ & $\begin{array}{ll}\text { 猚 南 南 } \text { 應 應 南 } \\
\text { 下一宮 宮 } \text { 上一上一宮 }\end{array}$ \\
\hline $\begin{array}{c}\text { 청산별곡 5행 제1정간-제14정간 } \\
\text { (시용향악보) }\end{array}$ & 下一宮 宮上二上一 \\
\hline
\end{tabular}

<강보> 7-9행의 ‘芜姑太姑(오음약보로는 下一下二 下三下二임)'의 선율과 <청산별곡> 5행 제 15 정간부터 6 행 제 13 정간의 ‘下-下二下三下二’의 선율은 동일하 다[악보 7][악보 8].

악보 7. 〈강보〉 7-9행과〈청산별곡〉 5 행 제 15 정간-6행 제 16 정간의 악보 비교

\begin{tabular}{|c|c|c|c|c|}
\hline 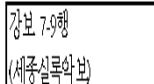 & 䒜 & in & th & tit \\
\hline 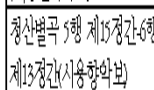 & $T-$ & F & $F \equiv$ & $F_{-}^{-}$ \\
\hline
\end{tabular}

악보 8. 〈강보〉 7-9행과〈청산별곡〉 5행 제15정간-6행 제 16 정간의 선율비교

\begin{tabular}{|c|c|}
\hline $\begin{array}{l}\text { 강보 7-9행 } \\
- \text { 세종실록악보 } \\
- \text { 오음약보로 바꾼 악보 }\end{array}$ & $\begin{array}{l}\text { 落 姑 太 } \\
\text { 下一下二下三下二 }\end{array}$ \\
\hline $\begin{array}{c}\text { 청산별곡 5행 제15정간-6행 } \\
\text { 제13정간(시용향악보) }\end{array}$ & 下-下二下三下二 \\
\hline
\end{tabular}

<강보> 10-12행의 '太姑獲應(오음약보로는 下三下 二下一上一임)'과 유사한 <청산별곡>의 선율은 6 행 제 6 정간부터 7행 제 5 정간까지의 ‘下二下-宮”이다. <청산 별곡>의 7행 제 4 정간에 나오는 “宮”이 <강보> 12 행에 서는 보이지 않고, '應(오음약보로는 宮)'으로 연주된다 [악보 9][악보 10].

악보 9. 〈강보〉 10-12행과 〈청산별곡〉 6행 제6정간-7행 제 5 정간의 악보 비교

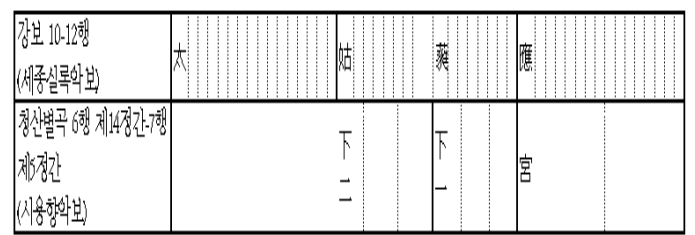

악보 10.〈강보〉10-12행과〈청산별곡〉6행 제14정간 -7 행 제 5 정간의 선율비교

\begin{tabular}{|c|c|}
\hline $\begin{array}{c}\text { 강보 10-12행 } \\
\text { - 세종실록악보 } \\
\text { - 오음약보로 바꾼 악보 }\end{array}$ & $\begin{array}{c}\text { 太 姑 落 應 } \\
\text { 下三下二下-上- }\end{array}$ \\
\hline $\begin{array}{c}\text { 청산별곡 6행 제14정간-7행 제5정간 } \\
\text { (시용향악보) }\end{array}$ & 下二下一宮 \\
\hline
\end{tabular}

<강보> 13-14행의 선율은 “萑南䕰姑太(오음약보로 는 下一宮下一下二下三임)'으로 이러한 선율은 <청산 별곡>의 8 행 제 12 정간부터 9행 제 8 정간까지인 '下一宮 下一下二下三”의 선율과 동일하다[악보 11][악보 12].

악보 11. 〈강보〉13-14행과〈청산별곡〉 8행 제12정간 -9 행 제8정간의 악보 비교

\begin{tabular}{|c|c|c|c|c|c|}
\hline 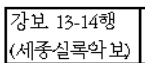 & 茗 & 南 & 茗 & 姑 & 太 \\
\hline $\begin{array}{l}\text { 청산별곡 8행 } \\
\text { 제12정간-9행 } \\
\text { 제8정간 } \\
\text { (시용향악보) }\end{array}$ & 下一 & 宮 & 下一 & 下 & $\begin{array}{l}F \\
\equiv\end{array}$ \\
\hline
\end{tabular}

악보 12. 〈강보〉13-14행과〈청산별곡〉 8행 제12정간 -9 행 제8정간의 선율비교

\begin{tabular}{|c|c|}
\hline $\begin{array}{c}\text { 강보 13-14행 } \\
- \text { 세종실록악보 } \\
- \text { 오음약보로 바꾼 악보 }\end{array}$ & $\begin{array}{c}\text { 落 南蓕 姑 太 } \\
\text { 下一宮下一下二下三 }\end{array}$ \\
\hline $\begin{array}{c}\text { 청산별곡 8행 제12정간-9행 제8정간 } \\
\text { (시용향악보) }\end{array}$ & 下一宮下一下二下三 \\
\hline
\end{tabular}

<강보> 15-16행의 '㒣㒣(오음약보로는 下四下四임)' 은 <청산별곡>의 10 행 제 1 정간부터 13 정간의 선율인 ‘下四下三下二下三下四' 중 ‘下四下四'를 발췌하였다. <청산별곡>의 10행에선 下四 다음에 下五로 종지하고 있으나, <강보> 16행에서는 ‘下四’로 마무리하고, 다시 <강보> 17행에서 <청산별곡>의 처음선율로 되돌아가 서<청산별곡>의 선율을 반복하여 발췌하고 있다. 그 러므로 <강보> 16행에서는 ‘下五”로 끝나는 완전종지 의 모습은 보이지 않는다[악보 13][악보 14].

악보 13. 〈강보〉15-16행과〈청산별곡〉10행 제 1 정간제 13 정간의 악보 비교

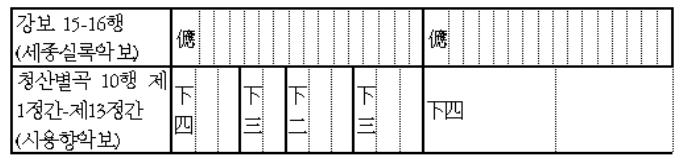


악보 14. 〈강보〉15-16행과〈청산별곡〉 10 행 제 1 정간제 13 정간의 선율비교

\begin{tabular}{|c|lr|}
\hline $\begin{array}{l}\text { 강보 15-16행 } \\
- \text { 세종실록악보 } \\
\text { - 오음약보로 바꾼 악보 }\end{array}$ & 雀 \\
\hline $\begin{array}{c}\text { 청산별곡 } \\
\text { 10행 제 } 1 \text { 정간-제13정간 } \\
\text { (시용향악보) }\end{array}$ & 下四下三下二下三下四 \\
\hline
\end{tabular}

<강보>의 1 행부터 16 행까지는 <청산별곡>의 3 행부 터 10행까지를 간헐적으로 한번 연주하였다. 다시 <강 보>의 17행부터 구체적으로 살펴보도록 하겠다.

<강보>의 17-20행은 '上一'과 '上二'가 반복되는 선 율로 <청산별곡>의 1-2행의 선율과 많이 유사하다. <강보> 17-20행의 선율이 '應汰汰應應(오음약보로는 上一上二上二上一上一임)'으로 <청산별곡> 1 행 제 4 정 간부터 2 행 제 3 정간까지의 '上一上一上二上一宮上一'의 선율 중 “宮”을 제외한 '上一上一上二上一上一'의 선율 과 거의 유사하다고 할 수 있다[악보 15][악보 16].

악보 15. 〈강보〉 17-20행과〈청산별곡〉1-2행의 악보 비교

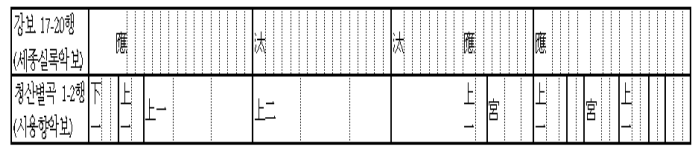

악보 16. 〈강보〉17-20행과 〈청산별곡〉1-2행의 선율비교

\begin{tabular}{|c|c|c|}
\hline $\begin{array}{l}\text { 강보 } \quad 17-20 \text { 행 } \\
\text { - 세종실록악보 } \\
\text { - 오음약보로 바꾼 악보 }\end{array}$ & $\begin{array}{l}\text { 應 } \\
\text { 上一 }\end{array}$ & $\begin{array}{c}\text { 汰 汰 應 } \\
\text { 上應 } \\
\end{array}$ \\
\hline $\begin{array}{c}\text { 청산별곡 1-2행 } \\
\text { (시용향악보) }\end{array}$ & 下一上一上一上二 & 上一宮上一宮上一上一 \\
\hline
\end{tabular}

<강보> 21-22행의 ‘南應汰應南(오음약보로는 宮上 一上二上一宮임)'의 선율은 <청산별곡> 3 행 제 1 정간부 터 제 11 정간까지의 선율인 “宮上一上二上一宮”과 완전 히 일치한다[악보 17][악보 18].

악보 17. 〈강보〉 21-22행과〈청산별곡〉 3 행 제 1 정간제 11 정간의 악보 비교

\begin{tabular}{|c|c|c|c|c|c|}
\hline \begin{tabular}{|l|} 
강보 21-22행 \\
(세종실록학보)
\end{tabular} & 南 & 㷳 & 太 & 應 & 南 \\
\hline $\begin{array}{l}\text { 청산별곡 3행제1 } \\
\text { 정간-제11정간 } \\
\text { (시용향학보) }\end{array}$ & 宮 & 上 & 上 & 上一 & 宮 \\
\hline
\end{tabular}

악보 18. 〈강보〉 21-22행과〈청산별곡〉 3행 제1정간-제 11정간의 선율비교

\begin{tabular}{|c|c|}
\hline $\begin{array}{l}\text { 강보 21-22행 } \\
\text { - 세종실록악보 } \\
\text { - 오음약보로 바꾼 악보 }\end{array}$ & $\begin{array}{l}\text { 南 應 汰一應 南 } \\
\text { 宮上一上——呂 }\end{array}$ \\
\hline $\begin{array}{c}\text { 청산별곡 3행 제1정간-제11정간 } \\
\text { (시용향악보) }\end{array}$ & 宮上一上二上一宮 \\
\hline
\end{tabular}

<강보> 23-26행의 선율은 “萑南南姑㹥(오음약보로 는 下一宮宮下二下一임)'이다. 이는 <청산별곡> 5 행의 제 1 정간부터 제 8 정간까지의 “下一宮宮”의 선율과 “获南 南'의 선율이 일치함을 볼 수 있다[악보 19][악보 20].

악보 19. 〈강보〉 23-26행과 〈청산별곡〉 5행 제1정간-제 8정간의 악보 비교

\begin{tabular}{|c|c|c|c|c|}
\hline 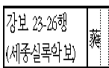 & 湳 & 南 & 活 & \\
\hline 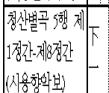 & 官 & 宮 & & \\
\hline
\end{tabular}

악보 20. 〈강보〉 23-26행과〈청산별곡〉 5행 제1정간-제 8정간의 선율비교

\begin{tabular}{|c|c|}
\hline $\begin{array}{l}\text { 강보 23-26행 } \\
\text { - 세종실록악보 } \\
\text { - 오음약보로 바꾼 악보 }\end{array}$ & $\begin{array}{l}\text { 蓶 南南 姑 茢 } \\
\text { 下一宮宮下二下一 }\end{array}$ \\
\hline $\begin{array}{c}\text { 청산별곡 5행 제1정간-제8정간 } \\
\text { (시용향악보) }\end{array}$ & 下一宮宮 \\
\hline
\end{tabular}

<강보> 27-29행 선율은 “豚姑姑太(오음약보로는 下 一下二下二下三임)'이다. 이는 <청산별곡> 5행 제15정 간부터 6 행 제 8 정간까지의 선율인 ‘下-下二下三’의 선 율을 발췌하였다고 할 수 있다[악보 21][악보 22].

악보 21. 〈강보〉 27-29행과〈청산별곡〉 5행 제15정간 -6 행 제8정간의 악보 비교

\begin{tabular}{|c|c|c|c|c|}
\hline 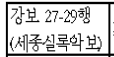 & 萟 & 姑 & 姑 & 太 \\
\hline $\begin{array}{l}\text { 청산별곡 } 5 \text { 해 } \\
\text { 제15정간-6행 } \\
\text { 제8정간 } \\
\text { (시용항학보) }\end{array}$ & F & F二 & & F三 \\
\hline
\end{tabular}

악보 22. 〈강보〉 27-29행과 〈청산별곡〉 5행 제1 정간-6 행 제8정간의 선율 비교

\begin{tabular}{|c|c|}
\hline $\begin{array}{l}\text { 강보 27-29행 } \\
- \text { 세종실록악보 } \\
\text { - 오음약보로 바꾼 악보 }\end{array}$ & $\begin{array}{c}\text { 茗 姑 姑 太 } \\
\text { 下一下二下二下三 }\end{array}$ \\
\hline $\begin{array}{c}\text { 청산별곡 5행 제15정간-6행 제8정간 } \\
\text { (시용향악보) }\end{array}$ & 下一下二 下三 \\
\hline
\end{tabular}


<강보> 30행의 선율인 '姑猫姑太(오음약보로는 下二 下一下二下三임)'와 <청산별곡>의 7행 제6정간부터 16 정간까지의 선율인 ‘下二下-下二下三’은 완전히 동일 한 선율이다[악보 23][악보 24].

악보 23. 〈강보〉 30 행과 〈청산별곡〉 7행 제6정간-제16정 간의 악보 비교

\begin{tabular}{|c|c|c|c|c|}
\hline $\begin{array}{l}\text { 강보 30행 } \\
\text { (세중실록학보) }\end{array}$ & 姑 & 苳 & 姑 & $太$ \\
\hline $\begin{array}{l}\text { 청산별곡 7행 제6정간-제16정간 } \\
\text { (시용향학보) }\end{array}$ & F & F & F & $\begin{array}{l}\text { 下 } \\
\Xi\end{array}$ \\
\hline
\end{tabular}

악보 24. 〈강보〉 30 행과 〈청산별곡〉 7행 제6정간-제16정 간의 선율비교

\begin{tabular}{|c|c|}
\hline $\begin{array}{l}\text { 강보 30행 } \\
\text { - 세종실록악보 } \\
\text { - 오음약보로 바꾼 악보 }\end{array}$ & $\begin{array}{l}\text { 姑 茟 姑 太 } \\
\text { 下二下-下二下三 }\end{array}$ \\
\hline $\begin{array}{c}\text { 청산별곡 7행 제6정간-제16정간 } \\
\text { (시용향악보) }\end{array}$ & 下二下-下二下三 \\
\hline
\end{tabular}

<강보> 31-32행은 <청산별곡>을 두 번째 반복하는 마지막 선율이다. <강보> 31-32행의 선율은 '應太太 (오음약보로는 下四下三下三임)'이고, 이는 <청산별 곡> 10 행중의 제 1 정간부터 제 12 정간까지의 ‘下四下三 下二下三’을 발췌한 것이다[악보 25][악보 26].

악보 25. 〈강보〉 $31-32$ 행과 〈청산별곡〉 10 행 제 1 정간제 12 정간의 악보 비교

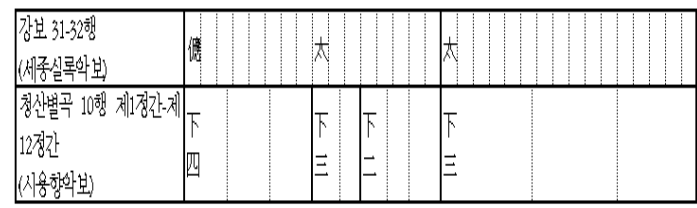

악보 26. 〈강보〉 $31-32$ 행과 〈청산별곡〉 10 행 제 1 정간제 12 정간의 선율비교

\begin{tabular}{|c|c|}
\hline $\begin{array}{l}\text { 강보 } \quad 31-32 \text { 행 } \\
\text { - 세종실록악보 } \\
\text { - 오음약보로 바꾼 악보 }\end{array}$ & $\frac{\text { 應 太 }}{\text { 下四下三 }}$ 下至 \\
\hline $\begin{array}{l}\text { 청산별곡 10행 } \\
\text { (시용향악보) }\end{array}$ & 下四下三下二下三 \\
\hline
\end{tabular}

<강보> 33행부터는 다시 <강보>의 세 번째 단락이 시작된다. <강보> 33-35행 제8정간의 선율은 “汰應南
(오음약보로는 上二上一宮)'이고, 이는 <청산별곡>의 1 행 제 9 정간부터 제 16 정간의 선율인 '上二上一宮'과 동 일하다[악보 27][악보 28].

악보 27. 〈강보〉 33 행-35행 제8정간과〈청산별곡〉1행 제9정간-제 16 정간의 악보 비교

\begin{tabular}{|c|c|c|c|}
\hline 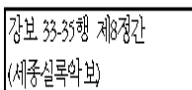 & 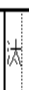 & 㷳 & 南: \\
\hline 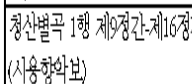 & E & 上 & 宮 \\
\hline
\end{tabular}

악보 28. 〈강보〉 33-35행 제8정간과 〈청산별곡〉1행 제9 정간-16정간의 선율비교

\begin{tabular}{|c|c|}
\hline $\begin{array}{l}\text { 강보 33-35행 제8정간 } \\
\text { - 세종실록악보 } \\
- \text { 오음약보로 바꾼 악보 }\end{array}$ & $\begin{array}{l}\text { 汰 應 南 } \\
\text { 上一一宮 }\end{array}$ \\
\hline $\begin{array}{c}\text { 청산별곡 1행 제9정간-제16정간 } \\
\text { (시용향악보) }\end{array}$ & 上二上一宮 \\
\hline
\end{tabular}

<강보> 35행 제9정간부터 38행 제8정간의 선율은 “應南應應(오음약보로는 上一宮上一上一임)'으로 <청 산별곡> 2 행의 선율인 '上一宮上一上一'과 완전히 일치 한다[악보 29][악보 30].

악보 29. 〈강보〉 35행 제9정간-38행 제8정간과 〈청산별 곡> 2 행의 악보 비교

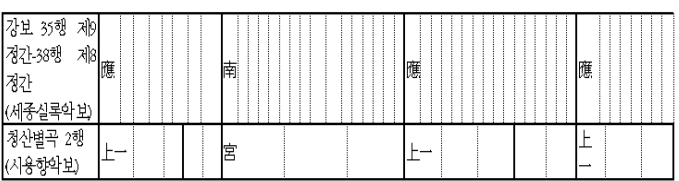

악보 30. 〈강보〉 35 행 제9정간-38행 제8정간과 〈청산별 곡> 2행의 선율비교

\begin{tabular}{|c|c|}
\hline $\begin{array}{c}\text { 강보 35행 제9정간-38행 제8정간 } \\
\text { - 세종실록악보 } \\
\text { - 오음약보로 바꾼 악보 }\end{array}$ & $\begin{array}{l}\text { 應 南 應 應 } \\
\text { 上一亮上一上- }\end{array}$ \\
\hline $\begin{array}{c}\text { 청산별곡 2행 } \\
\text { (시용향악보) }\end{array}$ & 上一宮上一上- \\
\hline
\end{tabular}

<강보> 38행 제 9 정간-40행의 선율은 “南蓕猫姑(오음 약보로는 宮下一下一下二임)'으로 <청산별곡> 3행 제 14정간부터 4행 제8정간까지의 선율인 “宮下一下一下 二'와 완전히 일치한다[악보 31][악보 32]. 
악보 31. 〈강보〉 38행 제9정간-40행과〈청산별곡〉 3행 제 14 정간 -4 행 제 8 정간의 악보 비교

\begin{tabular}{|c|c|c|c|c|}
\hline 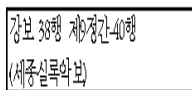 & 南 & 落 & 隣 & 枯 \\
\hline 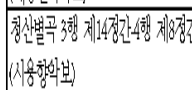 & 容 & - & $F$ & F \\
\hline
\end{tabular}

악보 32. 〈강보〉 39-40행과〈청산별곡〉 3행 제15정간 -4 행 제 8 정간의 선율비교

\begin{tabular}{|c|c|}
\hline $\begin{array}{c}\text { 강보 38행 제9정간-40행 } \\
\text { - 세종실록악보 } \\
- \text { 오음약보로 바꾼 악보 }\end{array}$ & $\begin{array}{l}\text { 南猚 菻 姑 } \\
\text { 呂下一下一下二 }\end{array}$ \\
\hline $\begin{array}{c}\text { 청산별곡 3행 14정간-4행 제8정간 } \\
\text { (시용향악보) }\end{array}$ & 宮下一下-下二 \\
\hline
\end{tabular}

<강보> 41행부터 44행의 선율은 “姑太姑萑南(오음약 보로는 下二下三下二下一宮)'로, <청산별곡> 6행 제 1 정간부터 7 행 제 5 정간까지의 선율인 '下二下三下二下 二下一宮'과 거의 일치하는 선율이다. <강보> 43 행에 서는 '姑(오음약보로는 下二임)'가 제 1 정간에 기보되어 있지만, 8정간에 걸쳐 연주되고 있는 것으로 볼 수 있 고, <청산별곡> 6행 제9정간과 14정간에 ‘下二’가 들어 가 있어, 결국 <강보> 43 행의 '姑'과 <청산별곡> 6행 제9정간과 14 정간의 ‘下二’를 동일선율 지속으로 볼 수 있다[악보 33][악보 34].

악보 33. 〈강보〉 41-44행과 〈청산별곡〉 6행-7행 제5정 간의 악보 비교

\begin{tabular}{|c|c|c|c|c|c|}
\hline 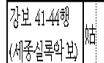 & $\hbar$ & |tit| & & 雚 & 南 \\
\hline 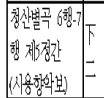 & $\bar{F}$ & : & 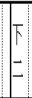 & - & 言 \\
\hline
\end{tabular}

악보 34. 〈강보〉 41-44행과 〈청산별곡〉 6행-7행 제5정 간의 선율비교

\begin{tabular}{|c|c|}
\hline $\begin{array}{l}\text { 강보 } \quad 41-44 \text { 행 } \\
\text { - 세종실록악보 } \\
\text { - 오음약보로 바꾼 악보 }\end{array}$ & $\begin{array}{ll}\text { 姑 太 } & \text { 姑 } \\
\text { 下二下三下二 } & \text { 下一莸 }\end{array}$ \\
\hline $\begin{array}{c}\text { 청산별곡 6행-7행 제5정간 } \\
\text { (시용향악보) }\end{array}$ & 下二下三下二下二下一宮 \\
\hline
\end{tabular}

<강보> 45-47행 제8정간은 “應萑姑太姑(오음약보로 는 上一下一下二下三下二임)'로 <청산별곡> 8행 제 14
정간부터 9행 제 12 정간까지의 선율인 “宮下一下二下三 下二’의 선율과 거의 유사하다[악보 35][악보 36].

악보 35. 〈강보〉 45-47행 제8정간과 〈청산별곡〉 8행 제 14 정간 -9 행 제 12 정간의 악보 비교

\begin{tabular}{|c|c|c|c|c|}
\hline 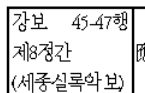 & 落 & 姑 & 太 & 姑 \\
\hline $\begin{array}{l}\text { 청산별곡 8행 } \\
\text { 제 } 14 \text { 정간-9행 } \\
\text { 제 } 12 \text { 정간 } \\
\text { (시용향학보) }\end{array}$ & F- & $\begin{array}{l}\text { F } \\
\text { E }\end{array}$ & \begin{tabular}{|l} 
F \\
三
\end{tabular} & $\begin{array}{l}\text { F } \\
\text { = }\end{array}$ \\
\hline
\end{tabular}

악보 36. 〈강보〉 45-47행 제8정간과 〈청산별곡〉 8행 제 14 정간 -9 행 제 12 정간의 선율비교

\begin{tabular}{|c|c|}
\hline $\begin{array}{l}\text { 강보 } \quad 45-47 \text { 행 제8정간 } \\
\text { - 세종실록악보 } \\
\text { - 오음약보로 바꾼 악보 }\end{array}$ & $\begin{array}{l}\text { 應 茗 姑 太 姑 } \\
\text { 上一下一下二下三下二 }\end{array}$ \\
\hline $\begin{array}{c}\text { 청산별곡 8행 14정간-9행 제12정간 } \\
\text { (시용향악보) }\end{array}$ & 宮 下一下二下三下二 \\
\hline
\end{tabular}

<강보> 47행 제9정간부터 48행의 ‘僱㑲(오음약보로 는 下四下五임')의 선율은 <청산별곡>의 10 행의 선율 인 '下四下三下二下三下四下五”의 선율중 간음을 제외 한 ‘下四’와 ‘下五”를 발췌하였다. <강보>도 45행부터 48행까지를 보면, 고려향악곡인 <청산별곡>과 마찬가 지로 ‘下--下二-下三-下四-下五”로 종지하는 하행종 지형을 갖고 있다[악보 37][악보 38].

악보 37. 〈강보〉 47행 제9정간-48행과 〈청산별곡〉10행 의 악보 비교

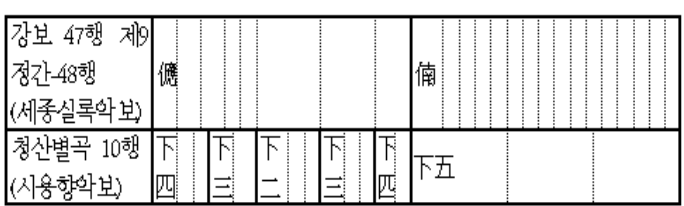

악보 38. 〈강보〉 47행 제9정간-48행과 〈청산별곡〉10행 의 선율비교

\begin{tabular}{|c|c|}
\hline $\begin{array}{l}\text { 강보 47행 제9정간-48행 } \\
\text { - 세종실록악보 } \\
\text { - 오음약보로 바꾼 악보 }\end{array}$ & $\begin{array}{l}\text { 㗹 } \\
\text { 下四 }\end{array}$ \\
\hline $\begin{array}{c}\text { 청산별곡 8행 14정간-9행 } \\
\text { 제11정간 } \\
\text { (시용향악보) }\end{array}$ & 下四下三下二下三下四下五 \\
\hline
\end{tabular}


지금까지 <강보>와 <청산별곡>의 선율 관계를 연 구해본 결과 <강보> 총 48 행은 <청산별곡> 1 행부터 10 행까지의 선율을 세 번 반복하였고, <강보> 역시 총 48행의 선율이 1-16행, 17-32행, 33-48행의 세 단락으 로 나눠진다고 할 수 있다. <강보>와 <청산별곡>의 선율관계를 나타내면 [표 8]과 같다.

\section{표 8. 〈강보〉와〈청산별곡〉의 선율 비교표}

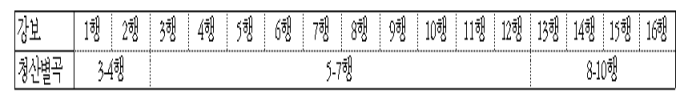

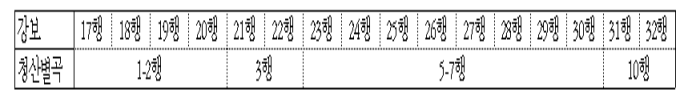

\begin{tabular}{|c|c|c|c|c|c|}
\hline 가여 & 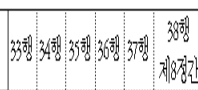 & 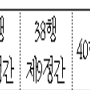 & 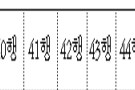 & 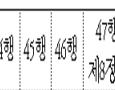 & 4 결 \\
\hline 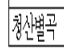 & 12.26 & 346 & $5-7 \rightarrow b_{b}$ & 89.96 & 1010 \\
\hline
\end{tabular}

[표 8]의 <강보>와 <청산별곡>의 선율을 살펴보면, 세종 때<발상> 중 <강보>는 고려향악곡인 <청산별 곡>에서 발췌된 곡임이 확인되었다. 이는 세종이 고취 악과 향악에 기하여 <정대업>, <보태평>, <발상>, $<$ 봉래의>를 만들었다는 기록에 근거하여[9], 실제 세 종이 고려 향악인 <청산별곡>에서 선율을 발췌하여 <발상> 중의 <강보>를 만들었다는 것이 이번 연구를 통해서 확연하게 증명된다.

세종이 <정대업> 중의 <휴명>을 <청산별곡>에서 [7], <화태(和泰)>를 <서경별곡(西京別曲)>에서[5], $<$ 보태평>중의 <형광(亨光)>을 <귀호곡(歸乎曲)>[13] 에서, <보예(保义) $>$ 를 <야심사(夜深詞) $>[14]$ 에서 발췌 하여 신악을 창제하였던 것처럼, <발상> 중의 <강보> 도 고려향악인 <청산별곡>에 근거하여 창제하였음을 이 연구에서 확인할 수 있었다.

\section{IV. 결론}

<청산별곡(靑山別曲)>은 고려시대에 지어진 작자 미상의 가요로『악장가사(樂章歌詞)』, 『악학편고(樂學 便考)』에 악보 없이 8 연의 가사가 전하고, 『시용향악보
(時用㰾樂譜)』에 악보와 함께 가사 제 1 연이 전한다.

<청산별곡>은 고려의 <대국>, 조선의 <납씨가>, <휴명>, <총유>, <경근지곡> 등에서 선율이 발췌되 거나, 조(調)가 바뀌고, 악곡의 길이가 증가되는 등 다 양하게 변모되어 전승되었다.

즉 <강보>와 <청산별곡>의 선율을 비교 분석한 결 과 48 행의 <강보>는 10 행의 <청산별곡>을 세 번 반복 하였는데, <강보>의 1-16행, 17-32행, 33-48행이 그 세 부분이다. <청산별곡>과 <강보>의 선율비교 결과 거 의 선율이 같거나 유사함을 알 수 있었다.

세종 때 <발상> 중의 <강보>가 고려 <청산별곡>을 발췌하여 신악으로 창제되었음을 이 연구에서 밝혀냈 다.

그동안 문헌에만 기록되어있고, 연주가 전승되지 않 아 <발상>의 음악을 전혀 알 수 없었으나, 이번 연구를 통하여 <발상>의 연주 재현이 가능해졌다. 왜냐하면 <강보>와 관련이 있는 <청산별곡>이 현재 재현되어 연주되고 있으므로, <청산별곡>의 연주에 비추어 이 연구를 토대로 <강보>의 연주를 재현할 수 있기 때문 이다[15][16].

세종 때의 <발상> 음악과 고려 음악과의 관계는 아 직까지 많은 연구가 이루어지지 않았으나, 이번 연구를 통해서 <발상>의 나머지 악곡들에 대한 고려음악의 전 승 고리를 풀 수 있을 것으로 생각된다.

\section{참 고 문 헌}

[1]『樂章歌詞』

[2]『樂學便考』

[3]『時用鄉樂譜』

[4] 張師勛, 國樂論放, 서울大學校出版部, p.72, 1980.

[5] 장사훈, 증보한국음악사, 세광음악출판사, p.276, 1986.

[6] 李惠求, 韓國音樂論叢, 秀文堂, pp.55-70, 1976.

[7] 이혜구역주, 세종장헌대왕실록 22, 세종대왕기념 사업회, pp.206-207, 1973.

[8]『世宗實錄』 
[9] 송방송, "조선왕조 건국초기의 정재사(呈才史) 연 구", 민족과 음악, 제23호, pp.193-232, 2002.

[10] 신대철, "세종대 이후 연산군대의 향악과 당악", 한국음악연구, 제29집, pp.99-100, 2001.

[11] 정경란, "고려 청산별곡(靑山別曲)의 현대적 습 용(襲用)", 고조선단군학, 제26호, pp.384-387, 2012.

[12] 국립국악원, 한국음악학자료총서 제20집, pp.79-80, 1986.

[13] 정경란, "고려 <귀호곡>과 종묘제례악 <형가> 의 관계", 국악원논문집, 제26집, pp.291-323, 2013.

[14] 정경란, "고려 야심사의 조선 종묘제례악 전승", 人文科學，제96집, pp.141-184, 2012.

[15] 서은숙, "한국문화 콘텐츠 개발의 필요성과 방향", 한국콘텐츠학회논문지, 제9권, 제1호, pp.417-427, 2009.

[16] 김지원, 류지성, "전통춤 디지털콘텐츠에 관한 문화예술정책 연구", 한국콘텐츠학회논문지, 제 12권, 제9호, pp.156-171, 2012.

\section{저 자 소 개}

정 경 란(Kyung Rhan Chung)

정회원

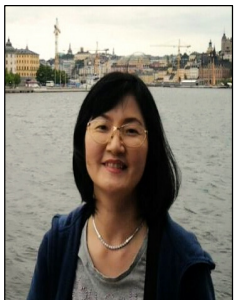

- 1984년 2월 : 서울대학교 음악대 학 국악과(학사)

- 1988년 8월 : 한국학중앙연구원 한국학과 음악학 전공(문학석 사)

- 2011년 8월 : 한국학중앙연구원 한국학과 음악학 전공(문학박사)

- 1989년 10월 현재 : 한국학중앙연구원 책임연구원

<관심분야> : 고려 및 조선시대 음악학 